\title{
On Demotivating Factors for English Learning of Vocational College Students in Leshan City, Sichuan, China
}

\author{
ZOU Li, XU Bo \\ Leshan Normal University, Leshan, China
}

\begin{abstract}
In the studies of the second language motivation, demotivation is comparatively new. More and more scholars have been studying demotivating factors in Second Language Acquisition (SLA) since the 1990s. The paper is to probe into the demotivating factors for English learning of vocational college students in Leshan City, Sichuan, China. About 250 students with different majors in Leshan Vocational and Technical College were involved in this study and they were asked to finish a close-ended questionnaire about demotivation in their English learning. By analyzing the data collected from the study, the author reached the following conclusions: The first, demotivation is a serious problem among vocational college students; the second, demotivation negatively affects the students' language proficiency in terms of the following four factors: learning failures, teachers' competence and teaching styles, lack of intrinsic motivation, and inadequate facilities and learning context. Besides, tentative proposals are further put forward with a hope to benefit English teaching in vocational colleges and minimize the students' demotivation.
\end{abstract}

Keywords: demotivating factors, vocational college students, English learning, motivation, demotivation

\section{Introduction}

\section{Definitions of Motivation}

Motivation is a term referring to a process that controls, elicits, and sustains certain behaviors. According to Dörnyei (2001), motivation is a general way of referring to the origins and causes of an action. Motivation involves the emotional, biological, cognitive, and social forces that activate our behaviors. Specifically, the term motivation is often used to describe why a man does something. For instance, we might say that a student is so motivated to get into an English program that she spends many years studying.

Harmer (2001) defined motivation as "some kind of internal drive that pushes one to achieve something" (p. 51).

According to Dörnyei, motivation is "a hypothetical and abstract concept" which explains people's behavior and thought in specific situations. Motivation regards two basic dimensions of human behavior: direction, a choice of a particular action, and magnitude, the effort made to the action and the persistence of this effort. Thus, motivation explains the reason why people determine to do something, how many efforts they make, and how

ZOU Li, associate professor, master, School of Foreign Languages, Leshan Normal University. XU Bo, associate professor, master, School of Foreign Languages, Leshan Normal University. 
long they persist in the activity. Besides, motivation is responsible for the tendency to choose a certain action, the effort made on the action, and the maintenance with it (Dörnyei \& Ushioda, 2011, p. 4).

According to the previous studies, motivation is so highly complicated that it is hard to define. The author describes motivation as the approaches to achieve goals in second language learning independently of whether the motivation is generated by external or internal incentives.

\section{Definitions of Demotivation}

Basically, demotivation is a comparatively new item in the field of seond language learning. Dörnyei has tried to define demotivation as follows: "demotivation is concerning specific external forces that reduce or cancel out the motivational basis of the behavioral intention or an ongoing action" (Dörnyei, 2001, p. 143). Dörnyei further clarified it by providing the following hypothetical examples (2001, p. 142). Jane lost her commitment to learn Spanish when her language class was devided into the more cometent and the less competent groups, and she was among the latter group. Jerry became demotivated to learn French when he did not understand a text and the teacher talked to him in an impatient and rude manner. Thus, a learner who is experiencing demotivation is one whose interest or commitment has been diminished (Dörnyei, 2001).

\section{Previous Studies of Demotivation}

Gary Chambers (1993) was one of the first researchers who studied demotivation in the field of second language learning. Chambers maintains that students hold that demotivation derives from the following different sources: second language learning experience, family, students' unsatisfied self-assessment, language teacher, etc.

Rebecca Oxford mainly focused on the teacher's impact on motivation. The study is based on the analysis of 250 papers written by American high schools and university students (Dörnyei \& Ushioda, 2011, p. 143). Oxford's study provides room and ground for future researches on demotivation, especially for those concerning teacher's influence on second language learning.

At home, researchers have studied a great deal of cases of demotivation in the Chinese English classrooms. KONG Zhe-qiong (2009) and ZHANG Zhe (2007) choose the ordinary university students as their study subjects of English learning demotivation, finding that teacher-related factors are the vital source of student's demotivation. But on the other hand, PAN Zheng-kai (2009) focuses on the vocational college students and the findings reckon learning environment-related factors as the most demotivating sources, a little different from other research results.

In sum, demotivation is a vital element in second language teaching and learning. But only a few researches have been done in order to analyze its role in the process of second language learning, so more research on demotivation is badly needed. Besides, most of the above-mentioned studies focus on students either high school students or ordinary university students and there is a lack of analysis on second language demotivation among students in vocational colleges.

\section{Study Design}

\section{Research Questions}

The three research questions are as follows: 
(1) What are the demotivating factors in second language learning for vocational college students?

(2) To what degree do more-motivated and less-motivated second languge learners differ in terms of demotivating factors?

(3) To what degree does demotivation affect the language proficiency of vocational college second language learners?

\section{Subjects}

The author chose about 250 students from a vocational college in Leshan City, Sichuan Province. The college where the author works is closely next to the vocational college, which makes it convenient to hand out questionnaires. Also, the author chose the vocational college for it is a key vocational college in Sichuan Province with students from different places of China, and it offers a wide range of courses, thus offering scientific and convincing data. All participants in this research have studied English at least from middle school to college.

The 250 participants consist of 106 male and 144 female, their age ranging from 18 to 20 . Their majors include Computer, Accounting, International Trade, Finance, and Hotel Management. Different majors all use the same textbooks and take the same English classes for at least one year, and in the process of English learning they usually suffer different degree of demotivation. Having studied English for so many years is also an important reason for demotivation during learning.

\section{Questionnaire Design}

It is proved that questionnaire is the most effective tool for quantitative studies. This study applies a close-ended questionnaire to probe into the demotivation of vocational college students' English learning.

The questionnaire is mainly composed of three parts. All the questions are written in Chinese in order to guarantee the correct comprehension of the questionnaire. The three parts are as follows:

Part 1 is about the participants' basic information like major, gender, and grade of College English Test Band 4.

Part 2 is about participants' demotivation status to make sure all of them have been experiencing demotivation in the process of English learning with four options: no motivation at all, a little motivation, moderate motivation, and high motivation. Based on the results, the leaners were divided into two groups: more motivated learners and less motivated learners.

Part 3 comprises 34 five-point Likert type questions about demotivation, adapted from Sakai and Kikuchi's study (2009), with minor changes based on the new subjects and previous studies. The participants are supposed to choose one of the five options of each item based on their own condition. The five options are rated by five-point-scale: 1 for "not true"; 2 for "mostly not true"; 3 for "true"; 4 for "mostly true"; and 5 for "absolutely true". Accordingly, the greater the point, the stronger the demotivating factor.

\section{Procedures}

The author invited one teacher of English in that vocational college to distribute questionnaires to a group of 50 students as a pretest, and then five teachers were invited to hand out the questionnaires to all 250 students as a main study. All the 250 participants received a questionnaire and a detailed explanation of how to finish it.

The questionnaire had been revised for many times before releasing to the participants, so that the questions could cover all the aspects and they were all correctly worded. The pretest was conducted in September 2015, followed by the main study in October 2015 . 


\section{Data Collection}

All the participants having finished the questionnaires, the author collected them from the five teachers of English and then computerized the data for further analysis. Altogether 245 questionnaires were valid, and the other five were excluded for three of the participants did multiple choices and two failed to finish all the questions. Besides, three students were found never experiencing demotivation in their English study, so they should be ruled out in the final analysis. Thus, all together 242 questionnaires were available for further research.

\section{Data Analysis}

The collection of the data was followed by the analysis of those data. The first step of data analysis was to computerize all the collected data of the valid questionnaires for statistical analysis by SPSS16.0.

First of all, according to the responses in Part 2 of the questionanaire, the subjects were divided into two motivation groups: more motivated and less motivated. Those who had moderate or high motivation were regarded as more motivated ones while those who had no or little motivation were reckoned as less motivated ones. And then, an exploratory factor analysis was done on Part 3 for each group to testify and explore the factor structure of the questionnaire items. Finally, demotivating factors within each group were studied to testify the differences between the two groups for each factor.

\section{Analysis of the Research Results}

As mentioned above, the first research question asks what the demotivating factors are in English learning of Chinese vocational college students. Based on Sakai and Kikuchi's research (2009) which analyzed five demotivating factors, the author extracted the following six factors in this study: (1) learning content; (2) inappropriate handling with learning materials; (3) learning failures; (4) inadequate facilities and learning context; (5) teachers' competence and teaching styles; and (6) lack of intrinsic motivation.

The first demotivating factor is "learning content". The final goal of college English teaching is to improve students' communicative competence in English in real occasions, with speaking and listening abilities especially emphasized. Therefore, the traditional teaching style of only presenting basic language knowledge is far from satisfaction. In the study, it is found that teachers of English in vocational college still take the traditional style of mainly applying Grammar Translation Method in English class, for they firmly believe that vocational college students are short of the basic skills of English, so translation method can make a big difference in English class. By this method, the teacher uses Chinese a lot to teach complicated grammar and individual words without contexts and both the teacher and students rarely speak English in class. Obviously, this method fails to reach the goal of promoting students' communicative competence, only to result in boring and uninspiring English learning experience for the students. For one thing, English teachers tend to adopt the traditional method, which is out of date; for another, excessive English tests simply focus on testing students' vocabularies, grammar, translation, and writing skills while omitting their communicative competence. What is more, college English teachers often assign a lot of homework to students after class to complete teaching tasks, which does no good to the students because responsible students may spend extra time after class on understanding teachers' presentation, memorizing important points, and finishing exercises so that they can meet the demand while both physically and mentally exhausted. 
The second demotivating factor is "inappropriate handling with learning materials". This study separately puts learning content and learning materials onto two different factors while Sakai and Kikuchi hypothesized learning content and learning materials as one factor. It is true that there is no coursebook that can satisfy every student and it is also true that every student has their own special interests and needs towards learning materials. Nevertheless, it is the university authorities who decide coursebooks and related supplementary materials, while teachers' advice and students' basic interests as well as needs are barely taken into account. Thus, the learning materials cannot cater for the different levels of students' English proficiency. In addition, the old versions of the coursebooks which contain out-of-date topics cannot catch up with the fast development of the society, only to result in the students' questioning the practical meaning of learning English. What is more, some coursebooks are too stereotyped and pushy, and to some degree restrict teachers' initiative and creativity, thus, chances are that students lose passion and interest about the English class and gradually become demotivated.

The third demotivating factor is "learning failures", which involves students' failure in reaching certain learning goals, such as "failing to memorize English words, phrases as well as grammar", "failing to meet the teachers' expectations", and "failing to form the good habit of studying on their own". In previous studies, ordinary university students were studied as the participants while the researchers failed to touch these above-mentioned items. It is absolutely no doubt that college English is far more difficult with more comprehensive contents and demands than English learning in high school. In colleges, students are supposed to acquire higher level of English competence in terms of speaking, listening, reading, and writing. And for vocational college students who lack the equivalent English learning ability, the new English learning tasks are heavy and extensive. For this reason, learning failures of the students in vocational colleges seem unavoidable. What is more, there is a group of students in vocational colleges who had planned to enter better ordinary universities, but due to their accidentally bad performances in College Entrance Examination, they entered the vocational college where they became top students catching more attention from teachers in English class. In this case, when other students realize they can never match these top students in English study, their original self-confidence will gradually become diminished and even vanished.

The fourth demotivating factor is "inadequate facilities and learning context”. In Sakai and Kikuchi's research (2009), only the items relative to teaching facilities are involved in the factor while this study also involves learning context which aims to put emphasis on the significance of real-situated learning environment of foreign language. It is known that China is a monolingual country. Thus, Chinese students seldom get the opportunity to use English in a real English context and the English they learn is known as "dumb English". As a matter of fact, English communicative activities are neither practical nor adequate. For one thing, communicative activities are sometimes neglected or even skipped by the teachers because this kind of activities takes a lot of time; for another, teachers are under great pressure to accomplish teaching assignment of course delivery and prepare the students for a lot of exams, as well as to write research papers for career development; what is more, vocational colleges fail to offer up-to-date audio or visual teaching facilities. In this case, the limited opportunities to practice English even in classrooms directly result in students' demotivating experience.

The fifth demotivating factor is "teachers' competence and teaching styles". More specifically, this factor includes the teacher's personality, competence, personal relationship with the students, devotion to teaching, 
attention paid to the students and teaching method as well as teaching style. And the result of the research is more or less in accordance with that of the previous studies. As Gorham and Christophel's study (1992) put it, about $79 \%$ of students' demotivation is triggered by negative teachers' behavior. And later Dörnyei and Ushioda noted that "the general finding that negative teacher behavior is perceived as central to students' demotivation is in line with the results obtained in the L2 field" (Dörnyei \& Ushioda, 2011, p. 141). As we know, teachers' job is to impart knowledge and educate people by delivering learning strategies as well as transmitting wisdom. So teachers play a vital role in initiating students' learning motivation. But on the other hand, teachers are also likely to play a demotivating part in a typical teaching process, although most of the time they unconsciously present the negative influence. Hopefully, teachers are able to fully realize that many of their behaviors in class can cause demotivation on students' English learning, for example, often failing to pay enough attention to the individual student in class; frequently criticizing students in an inappropriate way; being incapable of giving comprehensible explanations of the language points; consistently adopting old and dull teaching materials and inferior teaching facilities; their English pronunciation being poor.

The last demotivating factor is "lack of intrinsic motivation" which was defined by Sakai and Kikuchi (2009). Their findings demonstrate that upper secondary school students in Japan consider intrinsic forces as a vital source of demotivation. Based on these findings, it is safe to conclude that demotivation includes not only internal factors but also external factors. While in Chinese universities, non-English-major students usually have to take a lot of English examinations, which means that the motivation of learning English for most students is examination-oriented. What makes things worse is that students in vocational colleges put more energy in the specialized courses which in their eyes seem more practical and useful than learning English. The only purpose for them to learn English is external rewards, such as, to get better grades in tests and to find good jobs with certain certificates instead of enjoying the pleasure of the learning language. In a word, motivation comes from extrinsic sources, and demotivation derives from intrinsic deficiency.

\section{Conclusion}

As the title suggests, this research intends to probe into the demotivating factors for vocational college students' English study, and the main findings can be stated as follows:

For the first research question, this research makes the use of factor analysis method to extract the above-mentioned six factors based on the participants' answers to the questionnaires: (1) learning content; (2) inappropriate handling with learning materials; (3) learning failures; (4) inadequate facilities and learning context; (5) teachers' competence and teaching styles; and (6) lack of intrinsic motivation.

And for the second research question, this research concerns the difference between the two groups with low and high degrees of motivation. Great differences are found in factor 2, 3, 4, 5, and 6 between the less motivated participants and the more motivated participants. There is no obvious difference between the more motivated and the less motivated learners in terms of factor 1 "learning content", although the learners agree that it is a vital demotivating factor. Unlike the previous findings, factor 5 "teachers' competence and teaching styles" is not found to be a main reason of demotivation for both groups. In addition, this study further finds that the less motivated learners consider factor 3 "learning failures", factor 4 "inadequate facilities and learning context", and factor 6 "lack of intrinsic motivation" to be more demotivating than the more motivated learners. The more 
motivated learners reckon factor 2 "inappropriate handling with learning materials" and factor 5 "teachers' competence and teaching styles" to be more demotivating than the less motivated learners.

Finally, for the third question, this research analyzes the relationship between demotivating factors and the learners' grades in College English Test Band-4, which is a national criterion to estimate English proficiency of the college students. And the results definitely show that factor 3 "learning failures", factor 4 "Inadequate facilities and learning context", factor 5 "teachers' competence and teaching styles", and factor 6 "lack of intrinsic motivation" negatively affect English proficiency of vocational college students. What is more, the research also finds that factor 3 "learning failure" and factor 6 "lack of intrinsic motivation" are the most important factors discouraging vocational college students from achieving high-level English proficiency.

\section{References}

Chambers, G. N. (1993). Taking the "de" out of demotivation. Language Learning Journal, 7, 13-16.

Dörnyei, Z. (2001). Motivational strategies in the language classroom. Cambridge: Cambridge University Press.

Dörnyei, Z. (2005a). Teaching and researching motivation. Beijing: Foreign Language Teaching and Research Press.

Dörnyei, Z. (2005b). The psychology of the language learner: Individual differences in second language acquisition. Mahwah, NJ: Lawrence Erlbaum

Dörnyei, Z., \& Ushioda, E. (2011). Teaching and researching motivation. Harlow: Pearson Education.

Gorham, J., \& Christophel, D. M. (1992). Students' perceptions of teacher behaviors as motivating and demotivating factors in college classes. Communication Quarterly, 40(3), 239-252.

KONG, Z. Q. (2009). Research on the demotivating factors affecting college English learning. Beijing: North China Electric Power University.

Oxford, R. L. (1994). Where are we with language learning motivation? Modern Language Journal, 78, $512-514$.

Oxford, R. L. (1998). The unraveling tapestry: Teacher and course characteristics associated with demotivation in the language classroom. Demotivation in foreign language learning. Paper presented at The TESOL'98 Congress, Seattle, WA.

PAN, Z. K. (2009). An investigation of learner demotivation in vocational college English learning. Jin Hua: Zhe Jiang Normal University.

Sakai, H., \& Kikuchi, K. (2009). An analysis of demotivators in the EFL classroom. System, 37(1), 57-69.

Thurstone, L. L. (1947). Multiple-factor analysis. Chicago: University of Chicago Press.

Trang, T. T., \& Baldauf, R. B. Jr. (2007). Demotivation: Understanding resistance to English language learning: The case of Vietnamese students. The Journal of Asia TEFL, 4(1), 79-105.

Ushioda, E. (1996). Learner autonomy 5: The role of motivation. Dubin, Ireland: Authentic Language Learning Ltd..

Vallerand, R. J. (1997). Toward a hierarchical model of intrinsic and extrinsic motivation. In M. P. Zanna (Ed.), Advances in experimental social psychology. San Diego: Academic Press.

Williams, M., \& Burden, R. (1997). Psychology for language teachers. Cambridge: Cambridge University Press.

ZHANG, Q. (2007). Teacher misbehaviors as learning demotivators in college classrooms: A cross-cultural investigation in China, Germany, Japan, and the United States. Communication Education, 56, 209-227.

ZHANG, Z. (2007). A study on demotivation of university non-English major students for learning of English. Zhang Chun: Ji Lin University.

ZHOU, C., \& WANG, W. (2012). Demotivators analysis of Chinese university EFL learners. Foreign Languages in China, 45, $48-55$. 